JOALL (JOURNAL OF APPIIEI) LINGUIS'TICS ANI) LI'TERA'TURE)

Vol. 4 No. 2, 2019

ISSN (print): 2502-7816; ISSN (online): 2503-524X

Available online at https:/ / ejournal.unib.ac.id/index.php/joall/index doi: http://dx.doi.org/10.33369/joall.v4i2.7774

\title{
THE ANALYSIS OF INFORMATION TECHNOLOGIES USAGE FOR ACADEMIC PURPOSES IN ENGLISH LANGUAGE TEACHING AND LEARNING AT UNIVERSITAS BANGKA BELITUNG
}

\author{
Herland Franley Manalu ${ }^{1}$ \\ University of Bangka Belitung
}

Corresponding email: herland.franley@gmail.com

\begin{abstract}
The use of Information Technologies (IT) tools has become very important requirements for teachers and students nowadays in achieving academic goals in higher education. The harness of computers, internet, e-mail, multi-media and other IT tools is indispensable and has a great influence on the process of language teaching and learning in an effort to improve the quality of education and to produce best human resources that not only having good competence in foreign language but also possessing great capabilities in the use of Information Technology to face the Industrial Revolution 4.0 era. The study seeks to find out the frequency and the purposes of IT usage by students and lecturers in the English learning environment. A questionnaire containing questions about the frequency and the use of IT in the teaching and learning process was disseminated to the students and the lecturers of the English Literature department at the University of Bangka Belitung. The study reveals that the lecturers and students show a positive attitude towards the use of IT tools and the harness of the tools in the process of teaching and learning is believed to be very useful.
\end{abstract}

Keywords: IT Tools, Language Teaching and Learning, English Courses

\section{INTRODUCTION}

Information Technologies (IT) tools in the present days are growing rapidly and learning media have been developed on mobile devices such as smartphones and tablets that are easy to carry anywhere. The rapid advancement of IT tools such as computers, multimedia, and projectors has an impact on the increasing number of IT tools possession for people around 
the world. The number of computers ownership and other multimedia devices by lecturers and students have also increased every year. In line with the increasing number of IT tools ownership by various parties, the need for English teaching and learning based on IT tools is increasing and it requires serious attention from teaching staff within universities (Dudeney, 2008; Warschauer and Meskill, 2000).

In the current era of Industrial Revolution 4.0, the use of IT tools in the process of teaching and learning foreign languages, especially English as an international language, is currently needed from primary level to higher education level. This happens because there are demands for the teachers to make variations in teaching methods in order to make the learning atmosphere more fun. As can be seen in real life that the current condition of the English learning process in each level of education is mostly boring for students. In general, the teaching and learning activities in Indonesia still implement traditional methods where the teachers only focused on textbooks to teach their students (Wheeler, 2001).

Teachers are expected to be able to harness various learning resources used as self-study materials, for example, tutorial CDs and DVDs or other multimedia tools. The plethora of IT tools used for teaching media can contribute to learning activities such as the use of computer and internet for academic purposes through blogs and academic information systems made for university. At the University of Bangka Belitung, the process of online learning is conducted through UBB e-Academic. This online learning media is expected to increase students' enthusiasm in engaging themselves with blended learning activities.

Teaching-aid based on IT tools is a system of teaching and learning using technological equipment such as computers, multimedia, internet, and others. So, by using this teaching-aid system the learning activities will enhance students' motivation to take part in lessons, do the tests, and get feedback from the computer (Kistow, 2011). The development of science and technology today has supported extraordinary progress in all fields and it has influenced the process of teaching and learning foreign languages. Now, English teachers not only relying on textbooks as teaching materials but also using computers and the internet with facilities and software for academic purposes in class. This is related to the fact that today's language teaching paradigm supports the use of new technology (Turner \& Taylor, 2002).

The Internet offers a very wide range of original materials that can facilitate the student-centered learning activity, which is the main characteristic of the Communicative Language Teaching (CLT) approach. Nevertheless, the use of IT tools as learning aids has not been maximized yet and they haven't even been effectively used in some universities to teach English. There are several barriers to its application in Indonesia, such as the 
possibility of negative influences which is feared to have an impact on the students. Nevertheless, the utilization of computers with teaching materials can be applied appropriately, so this paper will review the frequency and the use of IT tools for the academic purposes and whether IT tools provide significant results in its use. In contrast to the findings of Robertson (2002) who investigated the use of computers in all fields of learning in college, this paper reviews the frequency of use and the purposes of IT tools usage by students and lecturers on English courses at the University of Bangka Belitung and whether IT tools provide significant results in their use for academic purposes.

The use of IT tools can be applied to all types of subjects because its application can be seen as a learning method that raises creative behavior and develops language learners' motivation in learning foreign languages at the university level. This study purports to seek out whether the use of IT tools in the process of English learning at the University of Bangka Belitung is effective and IT tools provide significant results in their use in academic purposes.

\section{METHODS}

\section{Subjects}

The participants in this study were 90 students and 10 lecturers at the University of Bangka Belitung selected randomly. Students' age range is around 17 to 21 years old, while the lecturers are ranging from 23 to 55 years old. The education level of the lecturers is ranging from Master's to Doctor's degree.

\section{Instruments}

In this study, the questionnaire was used as a data elicitation device. The two different questionnaires consist of four parts given to the students and lecturers. All parts are based on the Robertson (2002) questionnaire, which was later edited to focus on using IT tools in English the teaching and learning at the University of Bangka Belitung. The questionnaires were administered when the students and lecturers having their break time and also given in class with the assistance of the lecturers who were in charge of the classes (Bailey, 2008).

\section{Data Analysis Procedure}

In the beginning, 97 questionnaires distributed to students and 12 questionnaires distributed to English lecturers at the University of Bangka Belitung. However, 7 students and 2 lecturers did not answer the questions appropriately, so that only 90 students and 10 lecturers are valid to be used in this study. The questionnaire which contains questions about the 
frequency and the use of IT tools are written in English and given to the students and lecturers when taking their breaks so the survey would not disrupt the teaching and learning process in the classroom. The researcher used comparative analysis to process the data from lecturers and students.

\section{FINDINGS}

Based on the results of comparative analysis of lecturer and student from the questionnaires, the researcher found that there are $97 \%$ students and $80 \%$ lecturers use the computers when they are at home. The frequency of computer use on campus is in the second rank, which is around $70 \%$ of students and 90\% lecturers use computers in the classroom. Students and lecturers have the same percentage for computer use in public places, like in libraries, canteens and internet cafes, which is around $70 \%$. For the ownership of IT equipment, $100 \%$ lecturers and $90 \%$ of students have a portable computer. However, for the ownership of Personal Computer (PC), the students dominate the lecturers' ownership which is compared in $76 \%$ and $50 \%$. This matter is similar to the percentage of a computer interface to internet use, namely $80 \%$ for students and $70 \%$ for lecturers. Students and lecturers have the same percentage in the use of an e-mail account, which is $70 \%$.

The result of frequency analysis for the use of IT tools indicates that $40 \%$ of students use computers to type letters and other documents extensively which is more than 5 hours per week. There are $69 \%$ of students use a computer to do individual or group assignments such as typing presentation assignments, doing language exercises using a CD and watching videos from DVDs for 2-5 hours per week. Whereas $60 \%$ lecturers extensively ( $>5$ hours per week) use computers to type letters and other documents, $40 \%$ lecturers regularly use computers for preparing the presentation and learning materials in class and 50\% lecturers use a computer to prepare listening materials.

For the analysis of internet usage, $15 \%$ of students use a modem as an extensive internet connection media and 85 students use internet network on campus regularly. Whereas there are $10 \%$ lecturers use modems extensively and $90 \%$ lecturers use internet networks on campus periodically. The use of the internet for students is mostly for communication purposes on social networks extensively is $60 \%$. There are $55 \%$ of students using the internet to find information about their hobbies and buy products online. While there are $50 \%$ lecturers use the internet for the purposes of communicating on social networks extensively. $30 \%$ lecturers use the internet to find information about their hobbies, update the status of the blog and buy products online. 
From the results of the analysis of the internet use for academic purposes, it is found that $48 \%$ students and $20 \%$ lecturers use the internet as a communication channel for learning objectives between lecturers and students or students and students. $45 \%$ of students and $80 \%$ lecturers regularly use the internet to search for information and material for courses. There are also $80 \%$ of students and $40 \%$ lecturers participating in UBB eacademic for academic purposes and also looking for certain subjects. $40 \%$ of students and 30\% lecturers practice their English language skills through websites like VoA, BBC and CNN.

Table 1. The use of IT tools for academic purposes

\begin{tabular}{l} 
Activity \\
\cline { 2 - 4 } the
\end{tabular}

Based on the analysis of the level of ability to use IT tools, the students and lecturers have very good abilities in operating Windows and Microsoft Office programs such as Words, Excels, and Power Points. $80 \%$ of students and $50 \%$ lecturers have the ability to use presentation software and search engines on the internet like Google, Yahoo or MSN. There are $60 \%$ of students and $40 \%$ lecturers who have intermediate abilities in developing a blog. From the analysis of student questionnaires and lecturers, it was also found that there are $70 \%$ students and $90 \%$ lecturers stated that the use of IT 
tools shows significant results for academic purposes as shown in figure 1 below:

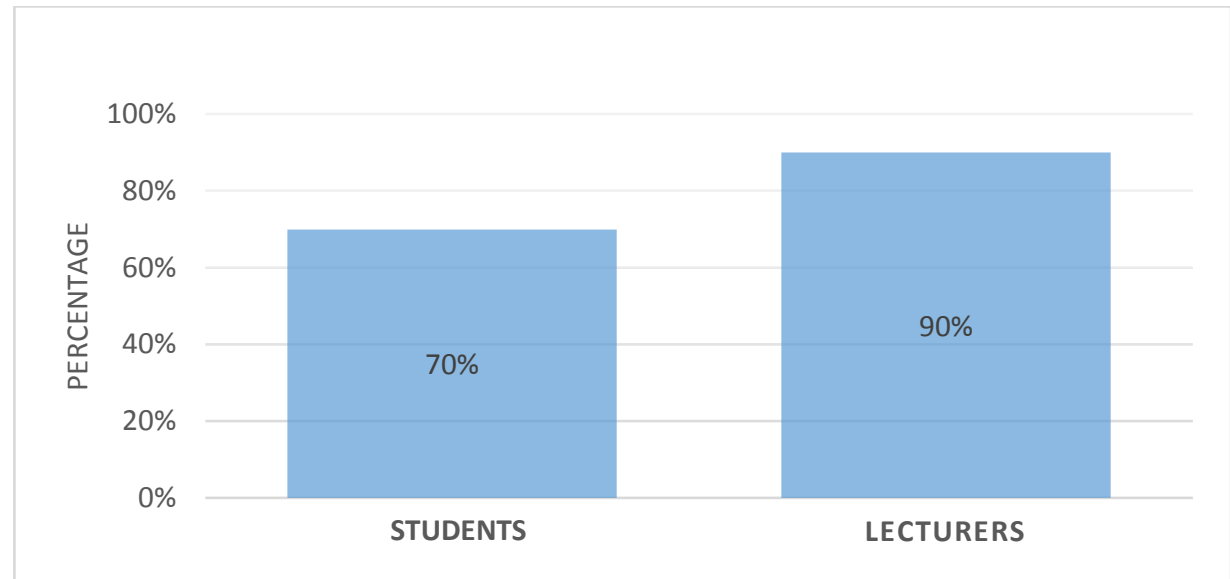

Figure 1. The significance of IT tools used for academic purposes at English Literature Department

\section{DISCUSSION}

Although this study only involved lecturers and students from one university and there is a possibility that they do not respond to questions listed in the questionnaire accurately, some implications for English teaching in Indonesia can be made based on findings on this study. The findings reveal the different capability of using IT tools for students and lecturers. Based on the results of the questionnaire analysis, it was found that most students master the Windows program and can develop the media. However, there is only a small number of lecturer master the Windows program and utilize the media. This is very surprising because the lecturers as the ones who teach students are expected to master the use of IT tools. The process of English teaching and learning will run well if the lecturers can master the use of IT tools.

The integration of foreign language learning by using IT tools can provide an active learning environment for learners (Chen, 2001). For example, when using internet students can get a cooperative learning atmosphere and different learning interactions through the learning process not only lecturers with students but also students with students. Social networking media like Facebook, Instagram or Twitter can also be used by lecturers and students to do learning activities such as sending their Speaking, Reading and Writing assignments.

Social networking media provide an environment where teaching and learning can generate excitement for students because they become more independent, without forgetting the standard of measuring the success of students. It is undeniable that students will be very interested in loving the learning activities through the online platform, and when students feel happy their desire to overcome new and difficult material will increase. 
The lecturers can upload listening tasks to the social networking media and students can send their speaking assignments. Based on the objectives of this survey, it can be concluded that the lecturers and students showed a positive attitude towards the use of IT tools in the process of language teaching and learning. This study also reveals that lecturers and students are active in learning foreign languages through the campus online learning system, UBB e-academic. It is also suggested lecturers get used to using IT tools so that the process of learning a foreign language can run effectively and efficiently.

\section{CONCLUSION AND SUGGESTION}

Based on the results of the lecturer and student questionnaire analysis, the researcher concluded that the implementation of IT tools for academic purposes is indispensable and it is suggested that the authorities in universities should provide the latest IT tools such as multimedia, computers, internet, and others to improve the learner's English skills and enhance the capability of teachers and students in harnessing technology (Davies and Smith, 2000).

The lecturers' capability in using the latest IT tools is very important because it is a must for them to build foreign languages learning interactions based on computer and internet networks to face the Industrial Revolution 4.0 era (Addison, 2011; Al-Said, 2015). Therefore, teachers' training for conducting language teaching and learning based on IT tools is needed. It is also necessary for the lecturers to improve the quality of English learning process because the students expected them to teach how to search for and use online learning resources through the internet since the students lacked information literacy search skills. To sum up, there should be a workshop for students and lecturers on how to harness IT tools in order to improve the English learning activities at the English Literature department within the University of Bangka Belitung.

Despite the above mentioned advantages of using technological tools, this study encounters some challenges. One of these challenges is low internet speed and internet connection problems. Another challenge of using IT tool such as a mobile application is the small-sized screen of the phones which makes it difficult for students to view all the course materials on the phone.

At last, the lecturers are also required to create syllabus and teaching materials to the online learning system to improve the process of blended learning. Therefore, the use of IT tools in English learning activities is highly appreciated by the lecturers and the students. Through the application of UBB e-academic at the University of Bangka Belitung, the students are 
The Analysis of Information Technologies Usage for Academic Purposes...

excited to learn and their creativity appear when practicing their English language skills.

\section{REFERENCES}

Addison, M. (2011). M-Learning: a cautionary tale. Training Journal. Retrieved June 19, 2019, from http://www.trainingjournal.com/blog/articlesblogs-m-learning-a-cautionary-tale/

Al-Said, K, M. (2015). Students' perceptions of Edmodo and mobile learning and their real barriers towards them. The Turkish Online Journal of Educational Technology, 14(2), 167-180.

Arifah, A. (2014). Study on the use of technology in ELT classroom: Teachers' perspective. M.A. Thesis, Department of English and Humanities, BRAC University, Dhaka, Bangladesh.

Bailey, N. (2008). Exploring Second Language Classroom Research. New York: Heinle.

Chen, Hong (2001). Empowering Chinese EFL teachers with technology: A computer applications course for English teachers. Proceeding at International symposium Technology in Language Education: Meeting the Challenges of Research and Practice, Hong Kong.

Dudeney, G. (2008). How to Teach English with Technology. Pearson Longman. Robertson, D. (2002). The new Renaissance: Computers and the next level of Civilization. Oxford: University Press.

Kistow, B. (2011). Blended learning in a higher education: A study of graduate school of business, Trinidad and Tobago. Carribean Teaching Scholar Vol 1-2. November, $115-128$

Turner, R \& Taylor, F. 2002. Effectiveness of teaching general practitioners skills in brief. Oxford: University Press.

Wallace, A. (2014). Social Learning Platforms and the Flipped Classroom. international journal of information and education technology, 4 (4), 293-296.

Warschauer, M. \& Meskill, C. (2000). Technology and second language learning. In J. Rosenthal (Ed.), Handbook of undergraduate second language education (pp. 303-318). Mahwah, New Jersey: Lawrence Erlbaum.

Wheeler, S. (2001). Information and communication technologies and the changing role of the teacher. Journal of Educational Media, 26 (1), 717. 